\title{
Distribution and agroclimatic characterization of potential cultivation regions of physic nut in Mexico
}

\author{
Carlos Alberto Núñez-Colín ${ }^{(1)}$ and María Antonieta Goytia-Jiménez ${ }^{(2)}$
}

${ }^{(1)}$ Instituto Nacional de Investigaciones Forestales, Agrícolas y Pecuarias, Campo Experimental Bajío, Km 6.5 Carretera Celaya-San Miguel de
Allende, Apartado Postal 112, (38110) Celaya, Guanajuato, México. E-mail: lit007a@gmail.com (2)Universidad Autónoma Chapingo, Departamento
de Preparatoria Agrícola, Km 38.5 Carretera México-Texcoco, 56230, Chapingo, Estado de México, México. E-mail: magoytia02@hotmail.com

\begin{abstract}
The purposes of this study were to determine the distribution and climatic patterns of current and future physic nut (Jatropha curcas) cultivation regions in Mexico, and to identify possible locations for in vivo germplasm banks establishment, using geographic information systems. Current climatic data were processed by Floramap software to obtain distribution maps and climatic patterns of regions where wild physic nuts could be found. DIVA-GIS software analyzed current climatic data (Worldclim model) and climatic data generated by $\mathrm{CCM} 3$ model to identify current and future physic nut cultivation regions, respectively. The distribution map showed that physic nut was present in most of the tropical and subtropical areas of Mexico, which corresponded to three agroclimatic regions. Climate types were $\mathrm{Aw}_{2}, \mathrm{Aw}_{1}$, and $\mathrm{Bs}_{1}$, for regions 1,2 and 3 , respectively. Nontoxic genotypes were associated with region 2 , and toxic genotypes were associated with regions 1 and 3. According to the current and future cultivation regions identified, the best suitable ones to establish in vivo germplasm collections were the coast of Michoacán and the Isthmus of Tehuantepec, located among the states of Veracruz, Oaxaca and Chiapas.
\end{abstract}

Index terms: Jatropha curcas, biofuels, climate modeling, geographical information systems, germplasm collection.

\section{Distribuição e caracterização agroclimática de regiões potenciais para cultivo de pinhão-manso no México}

Resumo - Os objetivos deste estudo foram determinar a distribuição e os padrões climáticos de regiões de cultivo, atuais e futuras, do pinhão-manso no México, e identificar possíveis locais para o estabelecimento de bancos ativos de germoplasma, com uso de sistemas de informação geográfica. Os dados climáticos atuais foram processados pelo software Floramap, para obter mapas de distribuição e padrões climáticos de regiões onde plantas de pinhão-manso selvagens poderiam ser encontradas. Foi utilizado o software DIVA-GIS para análise dos dados climáticos atuais (modelo Worldclim) e dos dados climáticos gerados pelo modelo CCM3, para identificar regiões de cultivo atuais e futuras de pinhão-manso, respectivamente. O pinhão-manso está distribuído na maioria das zonas tropicais e subtropicais do México, que correspondem a três regiões agroclimáticas. Os tipos climáticos foram $\mathrm{Aw}_{2}, \mathrm{Aw}_{1}$ e $\mathrm{Bs}_{1}$ para as regiões 1, 2 e 3 respectivamente. Genótipos não tóxicos foram associados à região 2 , e genótipos tóxicos foram associados às regiões 1 e 3 . De acordo com as regiões de cultivo atuais e futuras identificadas, as mais adequadas para o estabelecimento de coleções in vivo de germoplasma são a costa de Michoacán e o Istmo de Tehuantepec, localizadas entre os estados de Veracruz, Oaxaca e Chiapas.

Termos de indexação: Jatropha curcas, biocombustíveis, modelagem climática, sistema de informação geográfica, coleção de germoplasma.

\section{Introduction}

Physic nut (Jatropha curcas L.) is a native species to tropical America and belongs to the family Euphorbiaceae. It can be naturally found in the tropical and subtropical regions of Mexico in both wild and semi-cultivated areas (Cano Asseleih, 1992). According to Heller (1996), Mexico and northern Central America are considered the center of the origin of physic nut; however, there is controversy about that.
Physic nut has been studied and used at a global level (Henning, 2004; Kureel, 2006; Jongschaap et al., 2007). Formerly considered an underutilized plant (Heller, 1996), nowadays physic nut has strong significance due to its high oil content, which is desirable for producing biodiesel, lubricating oils, and soap (Wiesenhütter, 2003). Because biofuels are an important source of alternative energy to offset the environmental impact caused by fossil fuel combustion, they are being globally studied. Developed countries 
of the NTB Network of European Union (Labrousse, 1998) indicate the development and exploration of biofuels as an alternative to avoid the shortage of oil and natural gas in the future. Moreover, physic nut is already being cultivated in Africa (Henning, 2004) and India for biodiesel production (Kureel, 2006).

In Mexico, two major variants of $J$. curcas have been reported: toxic and nontoxic genotypes (edible fruit). Cano Asseleih (1992) mentioned that the nontoxic genotypes are consumed in traditional foods in Totonaca's areas of the state of Veracruz. Some other nontoxic genotypes can be found in the state of Quintana Roo, and they are suitable for human and animal consumption (Makkar et al., 1998b).

There are few breeding programs (Jongschaap et al., 2007) and diversity studies published on physic nut (Basha \& Sujatha, 2007; Ganesh Ram et al., 2008; Gohil \& Pandya, 2008; Gupta et al., 2008; Makkar et al., 2008; Sun et al., 2008); however, none of them have been carried out in its origin center.

Germplasm collections can be used to support breeding programs (Zagaja, 1988). In the case of physic nut, the breeding programs could be focused on biodiesel and on human and animal food production. Furthermore, these collections would preserve this important natural resource and its wild relatives, considering their potential uses in the near future (Zagaja, 1988). For those reasons, it is essential to characterize the genetic resources of physic nut, as soon as possible, to know its diversity in Mexico.

The purposes of this study were to determine the distribution and climatic patterns of current and future physic nut cultivation regions in Mexico, and to identify possible locations for in vivo germplasm banks establishment, using geographic information systems.

\section{Materials and Methods}

Two hundred and ten passport data were collected from Jatropha curcas herbarium specimens, located in the Mexican and International herbaria. Those herbaria are incorporated to the Global Network about Biodiversity Information (REMIB) database of Mexico (Comisión Nacional para el Conocimiento y Uso de la Biodiversidad, 2008).

The first analysis was done to obtain the distribution and to estimate climatic patters using Floramap software, version 1.02 (Jones \& Gladkov, 1999). This software, based on geographic information systems, predicts and makes distribution maps of potential areas for climatic adaptation of wildlife species. It uses geographic location of herbarium specimens (latitude and longitude) to obtain data patterns of climatic conditions of places where the species could adapt themselves. This software considers monthly climate data of total rainfall, average temperature, and range of diurnal temperature. Prior to analysis, the rainfall data were transformed by mean rain power A transform formula - in this case, a coefficient of 0.4 was used (Jones \& Gladkov, 1999) - developed to make a comparable scale to temperature. All sorts of climatic data were used to estimate climatic patterns. The climatic patterns were obtained by means of the principal component analysis (PCA), in order to have a dataset with reduced dimensionality. In the PCA, the climatic data were weighted to obtain a multinormal distribution. Without the use of weights, all coefficients are equal to one. In the present work, the weights for the PCA were 0.8 in total rainfall, 0.94 in average temperature, and 1.26 in the variation of diurnal temperature. The four principal components used in Floramap software for physic nut distribution explained $95.13 \%$ of the total variance (Jones \& Gladkov, 1999; Jones et al., 2002). A physic nut probabilistic distribution map and the agroclimatic characterization of regions suitable for this species cultivation were obtained using climatic data and Ward's method of cluster analysis. The probabilistic maps were calculated using the minimal probability of $75 \%$ of finding $J$. curcas in Mexico. Floramap software has been successfully tested for Passiflora in Andean countries (Segura et al., 2003) and for Crataegus in Mexico (Núñez-Colín et al., 2008). In addition, this software was also used to define the best area to establish the core collection of Phaseolus in the Americas (Tohme et al., 1995).

The second analysis was done using DIVA-GIS software version 5.4 (Hijmans et al., 2004), to obtain a model of current suitable climatic regions for physic nut cultivation (Worldclim model) and a model to predict future suitable climatic regions (CCM3 model) in Mexico. Worldclim and CCM3 models were calculated using BioClim procedure, which is used to obtain suitable climatic regions based on climatic patterns from geographic location of herbarium specimens. It also calculates the models 
for suitable regions using different climatic databases. This approach has been tested successfully for prediction of suitable climatic zones of the sugarcane woolly aphid (Ceratovacuna lanigera Zehntner) in India (Ganeshaiah et al., 2003). The model of current suitable climatic regions was done based on Worldclim (Hijmans et al., 2005) database, with a resolution of $2.5 \mathrm{~min}$. In order to predict the future suitable regions, CCM3 model was used by considering climatic conditions with two times the current atmospheric concentration of $\mathrm{CO}_{2}$. The resolution used in CCM3 model was $2.5 \mathrm{~min}$. The identification of future cultivation regions with DIVA-GIS, based on CCM3 model (Govindasamy et al., 2003) and considering the global changing climate, due to the greenhouse effect, determined future possible migration of suitable regions of physic nut cultivation in Mexico. After the analysis of the current and future suitable cultivation regions obtained, the best suitable regions to establish in vivo germplasm collections were identified.

Floramap and DIVA-GIS analyses take into account only the climatic data of temperature and rainfall, but they do not consider other factors, such as soil or wind (Jones et al., 2002; Hijmans et al., 2004).

\section{Results and Discussion}

The potential natural distribution of physic nut in Mexico (Figure 1) included: the Mexican Pacific coast, from Sinaloa, in the border with Durango, to
Oaxaca; the Gulf of Mexico, mainly in Tamaulipas, at the northern border of Veracruz; central and southern Veracruz; and the Yucatán Peninsula. Besides, it comprised some locations in Chiapas.

The cluster analysis by Ward's method, using Floramap software, showed the agroclimatic patterns of regions where physic nut could be found. Three agroclimatic regions were identified (Figure 2). The agroclimatic region 1 showed $\mathrm{Aw}_{2}$ climate, which is warm (rainy tropical climate), with summer rainfalls, and has the highest rainfall values of all the Aw climate categories (García, 1974). Region 1 had higher rainfall and temperature values than the other two regions. Region 2 had $\mathrm{Aw}_{1}$ climate, which differs from $\mathrm{Aw}_{2}$ in lesser rainfall and lower temperature (García, 1974). Finally, region 3 had $\mathrm{Bs}_{1}$ climate, which is dry-warm (steppe climate), with summer rainfalls, and has the highest rainfall values of all the B climate categories (García, 1974). Region 3 was drier and colder than the other two regions.

According to the climatic patterns obtained, physic nut might be widely distributed in all the tropical and subtropical regions of Mexico. This finding agrees with work from Cano Asseleih (1992). Nonetheless, the distribution of $J$. curcas in Mexico reported by Cano Asseleih (1992) was underestimated.

Region 1 was located in an area comprising: Isthmus of Tehuantepec, between Oaxaca and Veracruz; Tabasco;

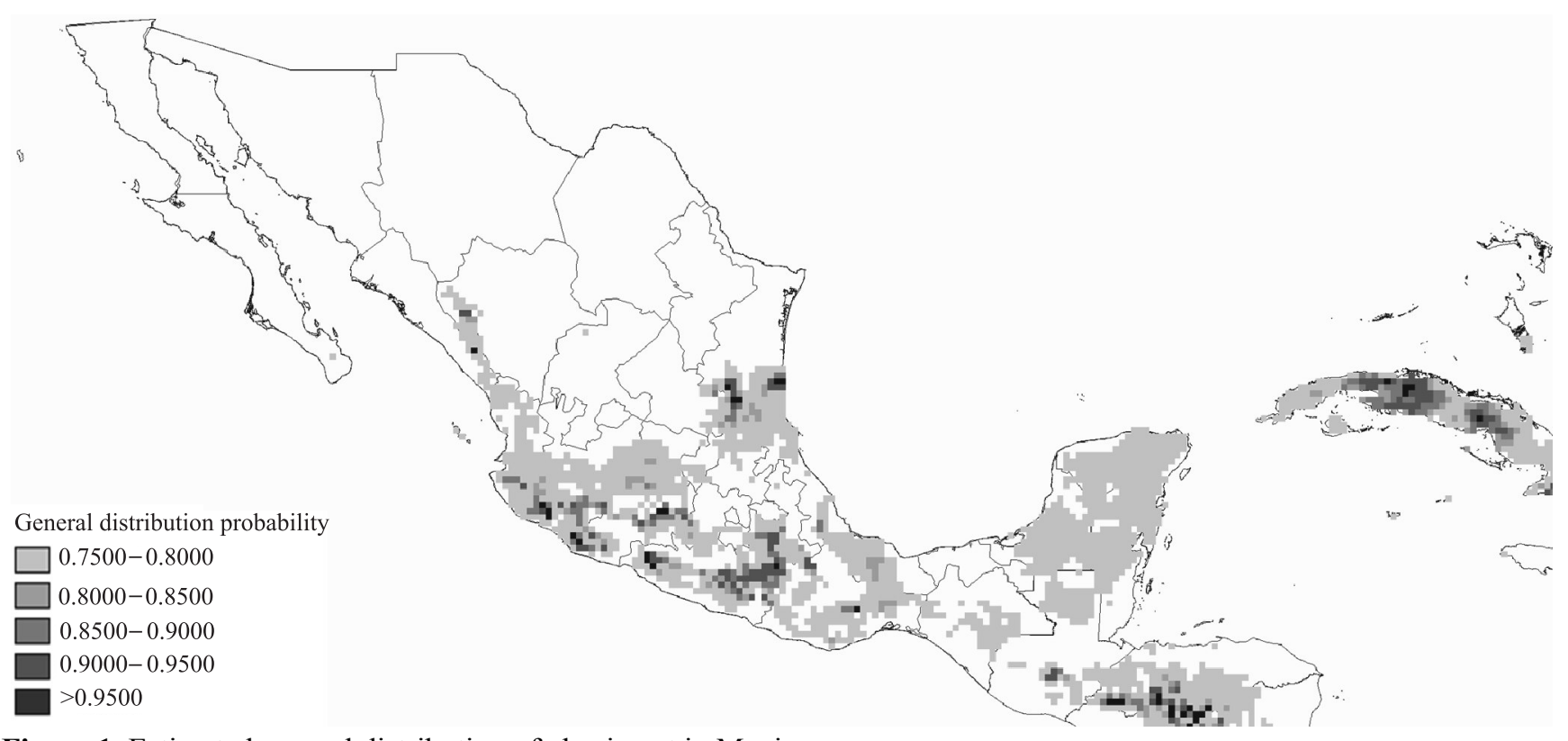

Figure 1. Estimated general distribution of physic nut in Mexico. 
northeast of Chiapas; and northern Veracruz. This region also comprised several isolated regions of the Pacific coast, from Sonora to Chiapas, and some locations in Los Cabos, Baja California Sur (Figure 3 A).
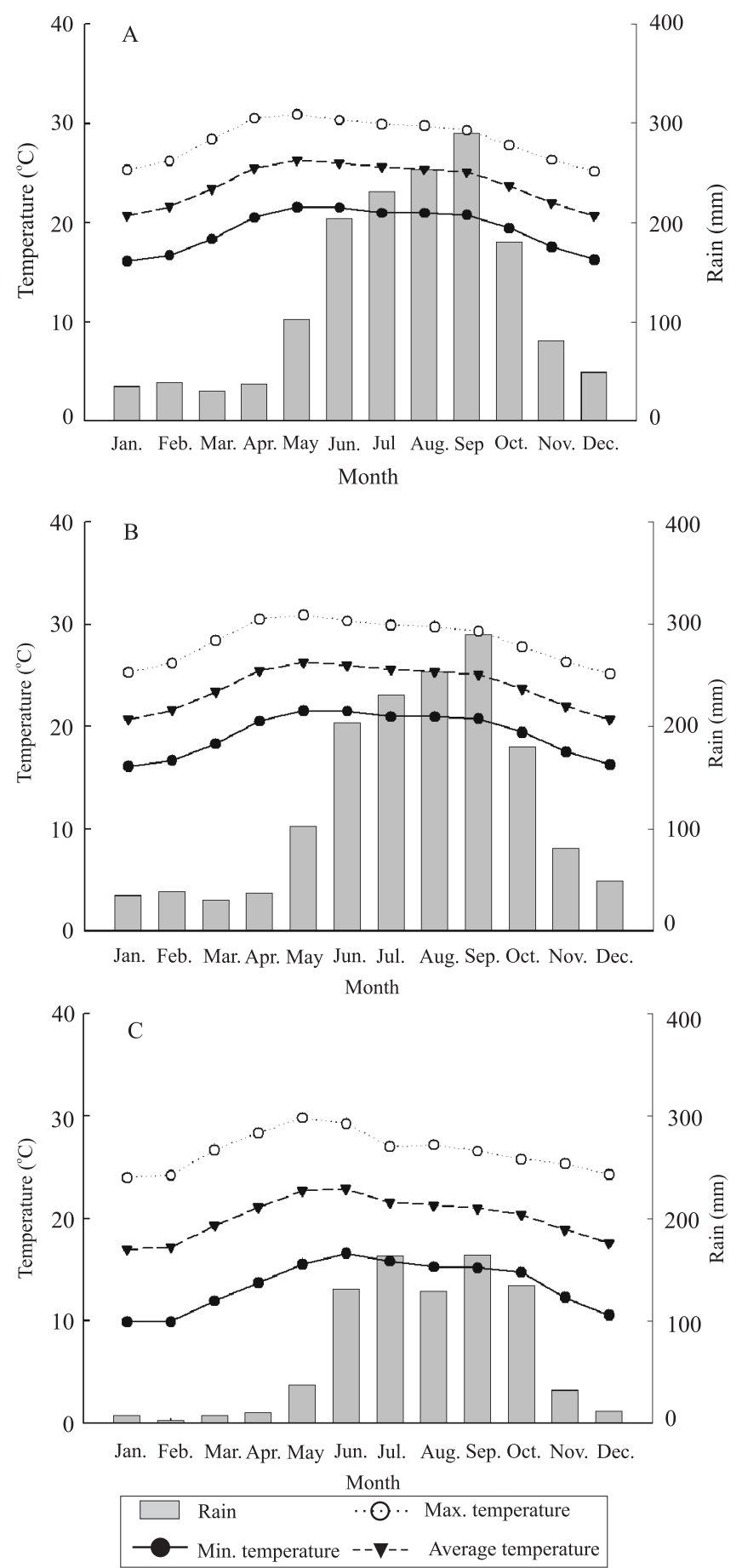

Figure 2. Climatograms of agroclimatic regions suitable for physic nut cultivation in Mexico. Region 1 (A, 24 points, $239.4 \mathrm{~m}$ a.s.l), region 2 (B, 62 points, $339.2 \mathrm{~m}$ a.s.l) and region 3 (C, 120 points, $1,599.5 \mathrm{~m}$ a.s.l).
Region 2 was distributed in northern and central Veracruz, and in the Yucatán Peninsula. It included some locations in the Guerrero coast, southern Chiapas, and the Mexicali valley, in Baja California (Figure $3 \mathrm{~B}$ ).

Region 3 comprised the Mixteca region among Puebla, Oaxaca, and Guerrero. In addition, it included some isolated locations in Nuevo León, Tamaulipas, San Luis Potosí, Guanajuato, Queretaro, Hidalgo, and Chiapas (Figure $3 \mathrm{C}$ ).

Nontoxic genotypes of $J$. curcas were reported in northern Veracruz (Cano Asseleih, 1992) and Quintana Roo (Makkar et al., 1998b). Considering the present agroclimatic characterization, the nontoxic genotypes were located in areas that corresponded to region 2. In fact, this region should be considered to plan collections of nontoxic genotypes. Nontoxic genotypes could be used for human and animal consumption (Makkar et al., 1998a; Chivandi et al., 2006; Martínez-Herrera et al., 2006). Toxic genotypes could be related to regions 1 and 3 and could be used to produce biodiesel (Zamarripa-Colmenero et al., 2008).

When planning collections of physic nut in Mexico, it is very important to take into account the agroclimatic regions obtained. Regions 1 and 3 have very contrasting climate, and the genotypes found there could be genetically different because of adaptation to the environmental conditions through their evolution (Dobzhansky, 1970). In order to have a complete and representative germplasm collection, genotypes from each agroclimatic region should be collected (Guarino et al., 2002). Thus the best target areas to collect representative specimens should be the areas from each region that showed more that $90 \%$ of probability of finding such genetic resource (Jones et al., 2002), based on the maps (Figure 3).

According to DIVA-GIS analysis, using Worldclim model, the current suitable climatic regions, where physic nut could be cultivated, were southern Sinaloa, the Michoacán coast, Tierra Caliente regions of Michoacán, central and southern Veracruz, and the Isthmus of Tehuantepec in Oaxaca. In addition, physic nut could be cultivated in Chiapas, southeast of Campeche and northeast of Yucatán, in the Quintana Roo border (Figure 4 A). Other regions where physic nut could be cultivated with less degree of adaptation were central Mexico, 


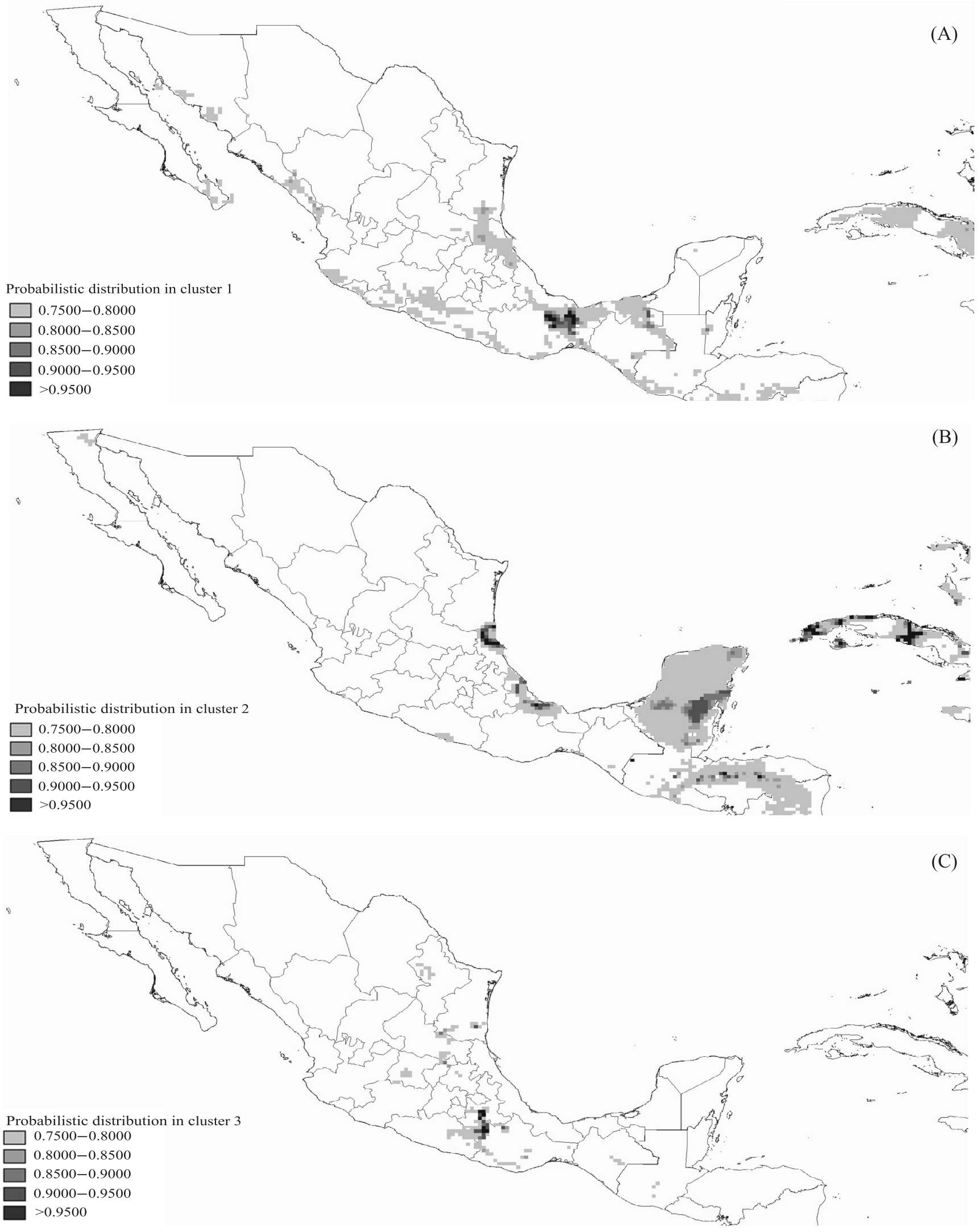

Figure 3. Estimated probabilistic distribution of physic nut in regions 1 (A, 24 locations), 2 (B, 62 locations) and 3 (C, 120 locations).

Pesq. agropec. bras., Brasília, v.44, n.9, p.1078-1085, set. 2009 

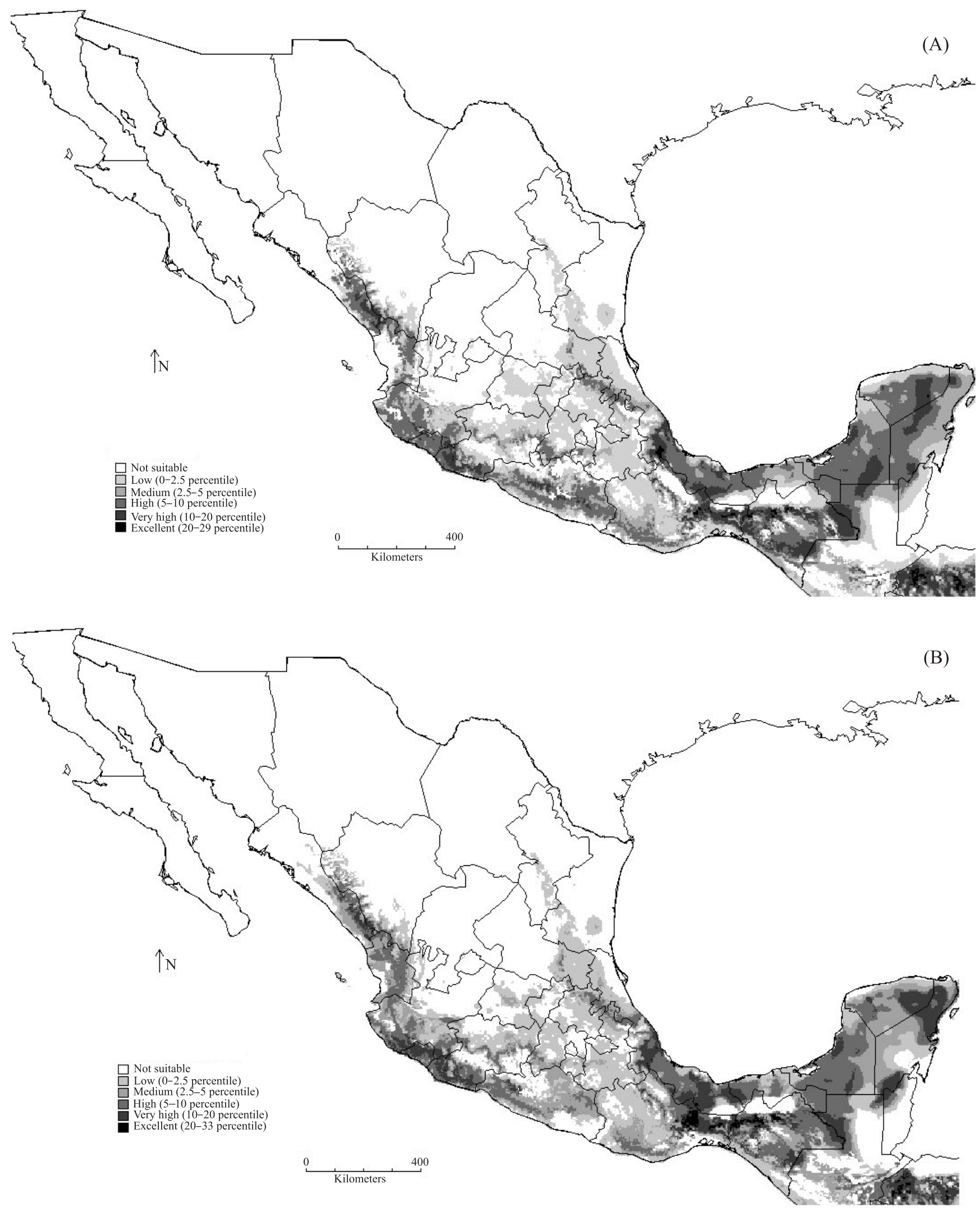

Figure 4. Suitable regions for physic nut cultivation in México, according to Worldclim database (A) and CCM3 model (B). 
the Pacific coast from Sinaloa to Chiapas and the Gulf of Mexico coast, from Tamaulipas, in the border with Nuevo León, to the Yucatán Peninsula.

The prediction of future suitable climatic regions, according to DIVA-GIS analysis using CCM3 model, showed that the best areas to grow physic nut would be southern Sinaloa and the central Pacific coast, from the southern coast of Jalisco to the Michoacán coast. Furthermore, the prediction included central and southern Veracruz, in the border with Tabasco, the Isthmus of Tehuantepec in Oaxaca, northern and eastern Chiapas and northern Quintana Roo, in the northeast Yucatán border (Figure 4 B).

The comparison between Worldclim and CCM3 models showed that the suitable cultivation regions would not change drastically. However, the adaptation regions would change mainly in the Pacific coast and in the Yucatán Peninsula. In addition, the areas obtained by Worldclim model matched the areas obtained by CCM3 model, but the degree of adaptation indicated by the CCM3 model was lower. As a result of this comparison, the best suitable regions, with greater climatic stability to establish in vivo germplasm banks, would be the Michoacán coast and the Isthmus of Tehuantepec, among Veracruz, Oaxaca, and Chiapas.

The results of this research could be useful for planning the best strategy to preserve physic nut genetic resources, to design correct germplasm collections (Guarino et al., 2002; Jones et al., 2002), and to establish the best places to set up in vivo germplasm banks of this species (Tohme et al., 1995; Hamilton et al., 2007).

\section{Conclusions}

1. Physic nut has a potential natural distribution in most of the tropical and subtropical areas of Mexico.

2. Physic nut can be found in three distinct agroclimatic regions in Mexico, and its nontoxic genotypes are related to $\mathrm{Aw}_{1}$ climate, and the toxic genotypes are related to $\mathrm{Aw}_{2}$ and $\mathrm{Bs}_{1}$ climates.

3. The regions with greater climatic stability, suitable to establish in vivo germplasm banks, are the Michoacán coast and the Isthmus of Tehuantepec, among Veracruz, Oaxaca and Chiapas.

4. The suitable physic nut cultivation regions in Mexico do not change drastically using the future climate scenario.

\section{Acknowledgments}

To Dalinda Sanchez Vidaña, for manuscript review.

\section{References}

BASHA, S.D.; SUJATHA, M. Inter and intra-population variability of Jatropha curcas L. characterized by RAPD and ISSR markers and development of population-specific SCAR markers. Euphytica, v.156, p.375-386, 2007.

CANOASSELEIH, L.M. El piñoncillo (Jatropha curcas L.): una especie oleaginosa con potencial de uso agroindustrial. Revista la Ciencia y el Hombre, v.10, p.131-138, 1992.

CHIVANDI, E.; ERLWANGER, K.H.; MAKUZA, S.M.; READ, J.S.; MTIMUNI, J.P. Effects of dietary Jatropha curcas meal on percent packed cell volume, serum glucose, cholesterol and triglyceride concentration and alpha-amylase activity of weaned fattening pigs. Research Journal of Animal and Veterinary Science, v.1, p.18-24, 2006.

COMISIÓN NACIONAL PARA EL CONOCIMIENTO Y USO DE LA BIODIVERSIDAD. Red Mundial de Información sobre la Biodiversidad (REMIB). México: CONABIO, 2008. Available at: $<$ http://www.conabio.gob.mx/remib/doctos/remib_esp.htlm>. Accessed on: 01 Oct. 2008.

DOBZHANSKY, T. Genetics of the evolutionary process. New York: Columbia University, 1970. 505p.

GANESH RAM, S.; PARTHIBAN, K.T.; SENTHIL KUMAR, R.; THIRUVENGADAM, V.; PARAMATHMA, M. Genetic diversity among Jatropha species as revealed by RAPD markers. Genetic Resources and Crop Evolution, v.55, p.803-809, 2008.

GANESHAIAH, K.N.; BARVE, N.; NATH, N.; CHANDRASHEKARA, K.; SWAMY, M.; SHAANKER, R.U. Predicting the potential geographical distribution of the sugarcane woolly aphid using GARP and DIVA-GIS. Current Science, v.85, p.1526-1528, 2003.

GARCÍA, E. Modificaciones al sistema de clasificación climática de Köppen. México: Universidad Nacional Autónoma de México, 1974. $71 \mathrm{p}$.

GOHIL, R.H.; PANDYA, J.B. Genetic diversity assessment in physic nut (Jatropha curcas L.). International Journal of Plant Production, v.2, p.321-326, 2008.

GOVINDASAMY, B.; DUFFY, P.B.; COQUARD, J. High resolution simulations of global climate, part 2: effects of increased greenhouse cases. Climate Dynamics, v.21, p.391-404, 2003.

GUARINO, L.; JARVIS, A.; HIJMANS, R.J.; MAXTED, N. Geographic Information Systems (GIS) and the conservation and use of plant genetic resources. In: ENGELS, J.M.M.; RAMANATHA RAO, V.; BROWN, A.H.D.; JACKSON, M.T. (Ed.). Managing plant genetic diversity. Rome: International Plant Genetic Resources Institute, 2002. p.387-404.

GUPTA, S.; SRIVASTAVA, M.; MISHRA, G.P.; NAIK, P.K.; CHAUHAN, R.S.; TIWARI, S.K.; KUMAR, M.; SINGH, R. Analogy of ISSR and RAPD markers for comparative analysis of genetic diversity among different Jatropha curcas genotypes. African Journal of Biotechnology, v.7, p.4230-4243, 2008. 
HAMILTON, R.S.; ENGELS, J.; VAN HINTUM, T. Consideraciones para mejorar los conceptos y estrategias de conservación y utilización. In: ENGELS, J.M.M.; VISSER, L. (Ed.). Guía para el manejo eficaz de un banco de germoplasma. Rome: Bioversity Internacional, 2007. p.49-67. (Manuales para Bancos de Germoplasma, 6).

HELLER, J. Physic nut. Jatropha curcas L. Rome: Institute of Plant Genetics and Crop Plant Research; International Plant Genetic Resources Institute, 1996. 66p. (Promoting the conservation and use of underutilized and neglected crop, 1).

HENNING, R.H. Jatropha curcas L. in Africa. Rome: Baganí and Global Facilitation Unit for Underutilized Species, 2004. 49p.

HIJMANS, R.J.; CAMERON, S.E.; PARRA, J.L.; JONES, P.G.; JARVIS, A. Very high resolution interpolated climate surfaces for global land areas. International Journal of Climatology, v.25, p.1965-1978, 2005.

HIJMANS, R.J.; GUARINO, L.; BUSSINK, C.; MATHUR, P.; CRUZ, M.; BARRANTES, I.; ROJAS, E. DIVA-GIS: sistema de información geográfica para el análisis de datos de distribución de especies. Version 4. Lima: International Potato Center, 2004. 83p.

JONES, P.G.; GLADKOV, A. FloraMap: a computer tool for predicting the distribution of plants and other organisms in the wild. Version 1.0. Cali: Centro Internacional de Agricultura Tropical, 1999. 99p.

JONES, P.G.; GUARINO, L.; JARVIS, A. Computer tools for spatial analysis of plant genetic resources data: 2. Floramap. Plant Genetic Resources Newsletter, n.130, p.1-6, 2002.

JONGSCHAAP, R.E.E.; CORRÉ, W.J.; BINDRABAN, P.S.; BRANDENBURG, W.A. Claims and facts on Jatropha curcas L.: global Jatropha curcas evaluation, breeding and propagation programme. Wageningen: Plant Research International, 2007. 60p. (Plant Research International, 158).

KUREEL, R.S. Prospect and potential of Jatropha curcas for biodiesel production. In: SINGH, B.; SWAMINATHAN, R.; PONRAJ, V. (Ed.). Biodiesel conference: towards energy independence - focus in Jatropha. New Delhi: India Government, 2006. p.43-74

LABROUSSE, S. NTB network - phase III. The Liquid Biofuels Newsletter, v.12, p.5-6, 1998.

MAKKAR, H.P.S.; ADERIBIGBE, A.O.; BECKER, K. Comparative evaluation of non-toxic and toxic varieties of Jatropha curcas for chemical composition, digestibility, protein degradability and toxic factors. Food Chemistry, v.62, p.207-215, 1998a.

MAKKAR, H.P.S.; BECKER, K.; SCHMOOK, B. Edible provenances of Jatropha curcas from Quintana Roo state of
Mexico and effect of roasting on antinutrient and toxic factors in seeds. Plant Foods for Human Nutrition, v.52, p.31-36, 1998b.

MAKKAR, H.P.S.; MARTÍNEZ-HERRERA, J.; BECKER, K. Variations in seed number per fruit, seed physical parameters and contents of oil, protein and phorbol ester in toxic and non-toxic genotypes of Jatropha curcas. Journal of Plant Science, v.3, p.260-265, 2008.

MARTÍNEZ-HERRERA, J.; SIDDHURAJU, P.; FRANCIS, G.; DÁVILA-ORTIZ, G.; BECKER, K. Chemical composition, toxic/ antimetabolic constituents, and effects of different treatments on their levels, in four provenances of Jatropha curcas L. from Mexico. Food Chemistry, v.96, p.80-89, 2006.

NÚÑEZ-COLÍN, C.A.; NIETO-ÁNGEL, R.; BARRIENTOS-PRIEGO, A.F.; SEGURA, S.; SAHAGÚN-CASTELLANOS, J.; GONZÁLEZ-ANDRÉS, F. Distribución y caracterización eco-climática del género Crataegus L. (Rosaceae subfam. Maloideae) en México. Revista Chapingo Serie Horticultura, v.14, p.177-184, 2008.

SEGURA, S.; D'EECKENBRUGGE, G.C.; LOPEZ, L.; GRUM, M.; GUARINO, L. Mapping the potential distribution of five species of Passiflora in Andean countries. Genetic Resources and Crop Evolution, v.50, p.555-566, 2003.

SUN, Q.B.; LI, L.F.; LI, Y.; WU, G.J.; GE, X.J. SSR and AFLP markers reveal low genetic diversity in the biofuel plant Jatropha curcas in China. Crop Science, v.48, p.1865-1871, 2008.

TOHME, J.; JONES, P.; BEEBE, S.; IWANAGA, M. The combined use of agroecological and characterization data to establish the CIAT Phaseolus vulgaris core collection. In: HODGKIN, T.; BROWN, A.H.D.; VAN HINTUM, T.J.L.; MORALES, E.A.V. (Ed.). Core collection of plant genetic resources. Rome: International Plant Genetic Resources Institute, 1995. p.95-115.

WIESENHÜTTER, J. Use of the physic nut (Jatropha curcas L.) to combat desertification and reduce poverty: possibilities and limitations of technical solutions in particular socio-economic environment, the case of Cape Verde. Bonn: Deutsche Gesellschaft für Technische Zusammenarbeit: Convention Project to Combat Desertification, 2003. 13p.

ZAGAJA, S.W. Exploración de recursos genéticos. In: MOORE, J.N.; JANICK, J. (Ed.). Métodos genotécnicos en frutales. México: AGT Editor, 1988. p.3-12.

ZAMARRIPA-COLMENERO, A.; DE LA PIEDRA-CONSTANTINO, R.; OLIVERA-DE LOS SANTOS, A.; GÓMEZ-SÁNCHEZ, D. Biocombustibles: perspectivas de producción de biodiesel a partir de Jatropha curcas L. en el trópico de México. Tuxtla Chico: Instituto Nacional de Investigaciones Forestales, Agrícolas y Pecuarias, 2008. 19p. (Folleto técnico, 6).

$\overline{\text { Received on February 2, } 2009 \text { and accepted on August 8, } 2009}$ 